\title{
Alluvial fan flooding in the Department of Pocito, Province of San Juan, Argentina
}

Gabinete de Neotectónica, Geology Institute, San Juan National University. Av. Ignacio de La Roza y Meglioli s/n. (5400) San Juan. Argentina. E-mail: lperucca@unsj-cuim.edu.ar

The study consists of the identification of landforms subject to alluvial fan flooding in active sectors of the Zonda range piedmont. In the Department of Pocito, located about $5 \mathrm{~km}$ southwest of San Juan City, a series of alluvial fans have been identified. These alluvial fans are located downstream of the natural drainage basins covering an area of approximately $130 \mathrm{~km}^{2}$ towards the eastern slopes of the Zonda range at a median elevation of 2,000 $\mathrm{m}$ a.s.l. The region is predominately arid, with an annual average precipitation of approximately 120 $\mathrm{mm}$. Torrential rains during summer can cause violent floods characterized by high transport speeds and relatively shallow depths. These floods can also transport a great volume of sediments and debris in a short period of time. Rainfalls usually have a short duration (less than 1 hour), a high intensity, and a reduced coverage area. This phenomenon is aggravated when the infiltration index is reduced further due to previous rains that saturate the area. The torrents generated in the high sloping mountainous region erode the existing rocks, carrying loose materials from the outcrops. As most of the piedmont is practically barren of vegetation, runoff becomes very rapid. The extent of active channels on the Zonda piedmont has been identified from geomorphologic studies of aerial photographs and land topography. The active areas are located at lower elevations relative to the adjacent older piedmont surfaces. Within the floodplain area, where the urban and rural areas are located, the majority of the historical records of floods have been confined to the location of 13th Street and 15 th Street, both oriented parallel to the slope down from the piedmont, on a west-east trend. During most rainfalls these streets have been transformed into natural riverbeds, influencing the path of the floods and limiting their damage to civil structures. As a result of this, other streets and a few irrigation channels laying a north-south trend have been seriously affected. The development of a predictive and early warning system, combined with public education and structural corrective measures are thought to be the means to minimize the hazard that alluvial fans floods pose over the Department of Pocito.

\section{Introduction}

Following a comprehensive study of the hazards of geological origin affecting the Department of Pocito, it has been detected that the two most important ones are the seismic and alluvial fan flooding hazards. In this paper the alluvial fan flooding hazard is analyzed by considering it the most important hazard in regards to the frequency of the occurrence of the events.

The waters of the torrential rains that are common in the summer months, by the time they reach a dry riverbed, are already carrying a great load of solid material. These floods are usually short-lived and violent, reaching relatively high transport speeds.

Large quantities of solid material such as sediments of various size ranges, uprooted vegetation and all sorts of debris are transported and later accumulated in the piedmont of the Sierra Chica de Zonda range.

Successive floods in recent years have caused the progressive filling of the existing dams and collectors built years ago to minimize the damages caused by floods, with subsequent increases in the costs of maintenance of these works.

\section{Location and population}

The Department of Pocito is located approximately $5 \mathrm{~km}$ southwest of San Juan City in an area known as the Tulum Valley, state of San Juan in the central western portion of Argentina Republic. The Department covers an area of $515 \mathrm{~km}^{2}$, comprising the western flank of the Chica de Zonda range, the eastern piedmont and the valley below (Figure 1).

The urban and rural zones of the Department of Pocito are located at about $600 \mathrm{~m}$ a.s.l. The highest landmarks in the region are the Rinconada (2,234 m a.s.1.) and the La Laja (1,754 m a.s.1.) hills.

The town of Pocito, the administrative center of the Department, has about 35,000 inhabitants and more than 7,000 buildings. The percentage of these which can be classified as precarious edifices vulnerable to flooding is relatively high, in some areas reaching up to $80 \%$. The town of Pocito is crossed from north to south by Highway 40, which connects the major cities of San Juan and Mendoza. The region has many private water wells and irrigation channels. The main distribution channel is known as 'Ingeniero Cespedes Channel', from which irrigation water is distributed to an irrigation network covering most of the Department. Mostly due to the harsh climatic conditions, the natural vegetation is scarce and it has been further affected by human activity.

\section{Economic activities}

The principal economic resources of the region are agriculture (grapevine, olive trees and vegetables), mining (small limestone and calcite quarries in the mountainous area), and a few artisan industries. Agriculture activity is located mainly in the valley areas, where 
there is available water supply through the irrigation network and private wells.

During recent years, though agricultural activity has been expanded towards the piedmont, altering the natural arrangement of the runoff channels with small dams, many of which have already been destroyed by recent summer floods.

\section{Climate}

The Province of San Juan is located within the arid belt of Argentina, a region characterized by scarce rainfall (below $100 \mathrm{~mm}$ per annum), low air humidity and high allophany. Maximum evapo-transpiration occurs during the spring-summer months, with minimums in the autumn-winter months.

Orography isolates this region from wet air, giving it an arid and highly continental character, with warm summers and cold winters (Poblete y Minetti, 1999). Within the study area, superficial runoff occurs as ephemeral torrents originated in the months of December to March due to summer rainfalls of short duration and high intensity. These torrents are generated in the mountainous areas, eroding the existing rocks and dragging along loose rocks from the limestone, sandstone and mudstone outcrops. This phenomenon is aggravated further when the infiltration index is reduced due to previous rains that saturate the area.

The annual average rainfall in the valley region, where the cultivated areas and populated centers are located, amounts to about $100 \mathrm{~mm}$ per annum, increasing slightly to $120 \mathrm{~mm} /$ annum towards the west due to the orographic influence of the Chica de Zonda range.

Monthly rainfall recorded at the INTA Pocito weather station has been summarized in Table 1 .

\section{Table 1 Summary of rainfall for the Pocito region}

\begin{tabular}{cccccc}
\hline INTA Pocito & January & February & March & December & Annual \\
$1968 / 1997(\mathrm{~mm})$ & 23,7 & 21,5 & 17,8 & 20,8 & 102,6 \\
\hline
\end{tabular}

More than $80 \%$ of the annual average rainfalls are registered during the four months of summer. During the October-March semester, associated the higher temperatures, almost $90 \%$ of the total rainfall takes place. Summer rainfall is usually associated with thunderstorms with intensive downpours.

\section{Geology and geomorphology}

The Eastern Precordillera Geological Province is characterized by several elongated mountainous ranges with a regional north-south trend, stretching between $31^{\circ} 00^{\prime} \mathrm{S}$ to $32^{\circ} 30^{\prime} \mathrm{S}$ latitude and paralleling $68^{\circ} 30^{\prime} \mathrm{W}$ longitude. Their main rock constituents are limestones, dolostone and marine clastic sediments of Early Paleozoic, continental rocks of Carboniferous and Tertiary, and Quaternary deposits.

The structure of the Eastern Precordillera is characterized by overthrusts dipping to the east. The structure is grouped within the Precordillera Oriental Fault System consisting of mainly Quaternary faulting affecting both edges of the mountainous ranges of the region (Bastias, 1986). The faults located in the eastern piedmont of Chica de Zonda range have reverse submeridianal trend affecting existing alluvial deposits of Pleistocene-Holocene age. These faults, dipping between $25^{\circ}$ to $50^{\circ}$ towards the east, have scarps against the slope, with slightly curved outlines and a concavity looking westward.

Water courses and other recent features such as terraces are constantly modified by faults, evidence of an active system showing on-going activity.

The Department of Pocito has three main landforms, from west to east (Figure 1):

- A mountainous area: located to the east of the water divide of the Chica de Zonda range, between Zonda Creek to the north, La Flecha Creek to the south, and the Tulum valley to the west. The average height varies between 1,500 to 2,000 m a.s.1.

- A piedmont area: the area connecting the mountainous area with the valley. This area consists mainly of mudstone, sandstone, and limestone clasts forming a succession of sandstone, conglomerate and mudstone banks of Tertiary age. The piedmont area lies at an average height of 700 to $900 \mathrm{~m}$ a.s.l.

- A valley area: corresponding to the soils of the ancient flood plain of the San Juan River. It lies at an average height of $650 \mathrm{~m}$ a.s.1.

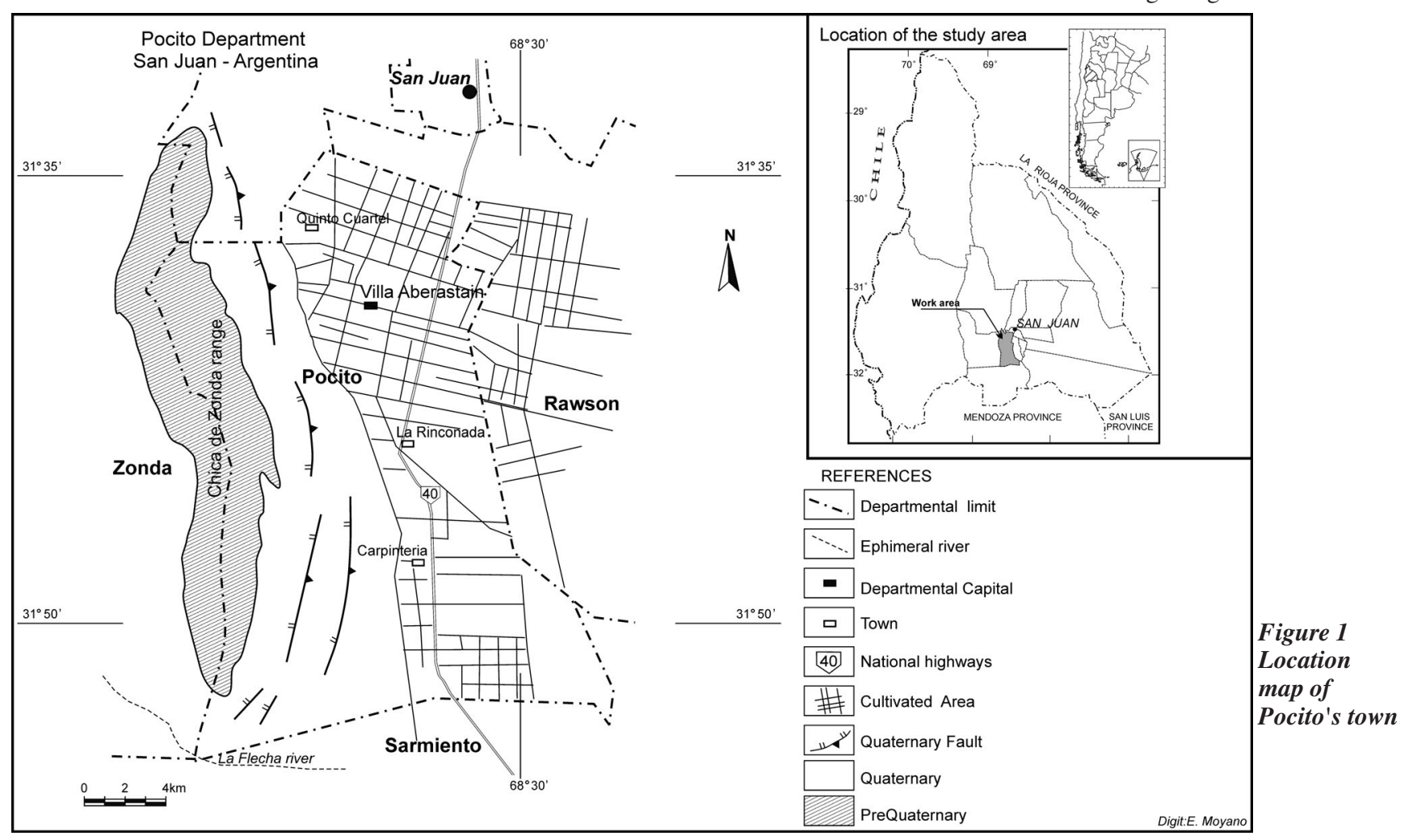




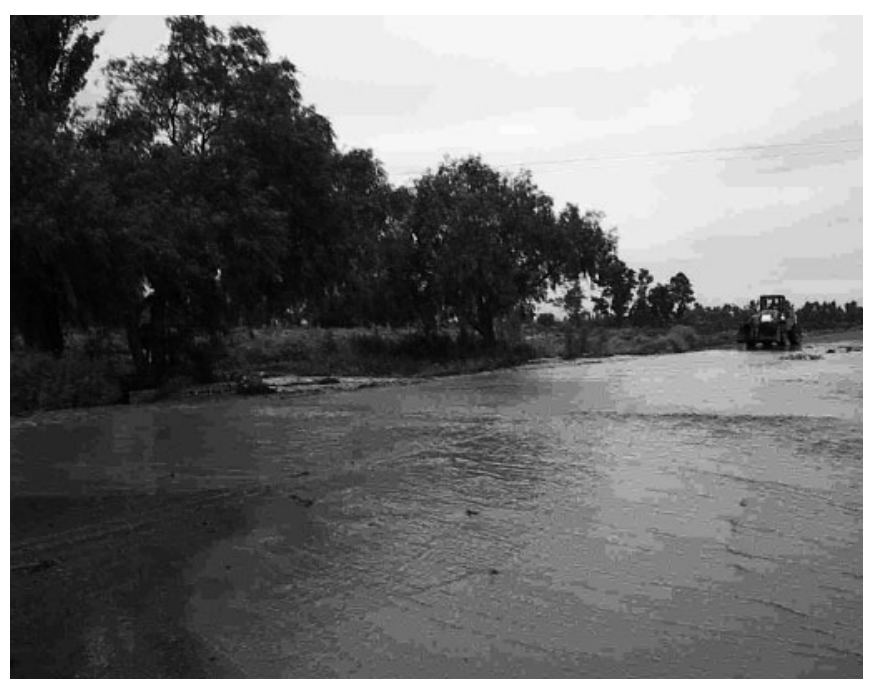

Figure 2 Flood crossing National highway 40. View to the south.

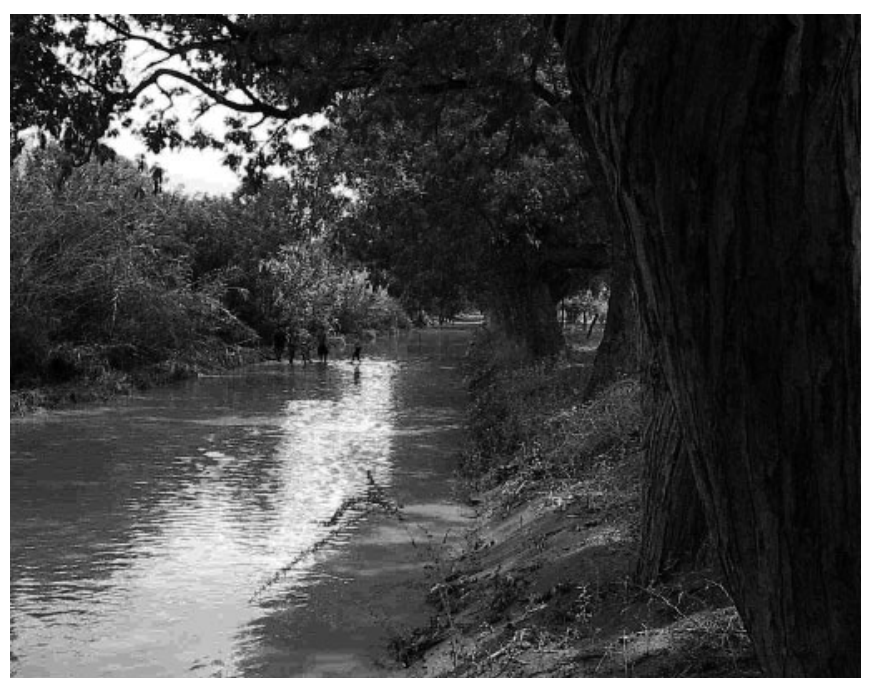

Figure 3 13th street, view to the west, March 8, 2003.

\section{Flooding history}

Debris deposits from Holocene floods were exposed in most of the observed watersheds along 13th and 15th streets. The dimensions of the largest boulders found in these prehistoric deposits as well as the deposit thicknesses were recorded.

The size of the boulders and the thickness of these prehistoric deposits are at least as large as those of the last 50 years and, in several areas, even larger. This seems to indicate that recent events were not the largest events to have occurred in this region.

During the last ten years, three floods of great magnitude were registered. They caused serious damage to houses, streets, crops and irrigation and potable water distribution networks.

A single major storm on February 25-26th, 1994, with rainfall in excess of $50 \mathrm{~mm}$, caused major flooding of Pocito. Damage to the community infrastructure was extensive, including the collapse of several precariously built houses and several flooded streets which led to some localities becoming isolated from outside help.

During the period from the night of December 26th, 1999 until dawn of the next day, a heavy storm of wind and rain exceeding 40 $\mathrm{mm}$ swept through the Department. One of the main arteries of the Department, 13th Street, became a natural riverbed. All defenses in place collapsed, damaging the Ingeniero Céspedes Channel, flooding houses and crop fields. The cesspools of several houses were waterlogged affecting the drinking water supply. The flood reached

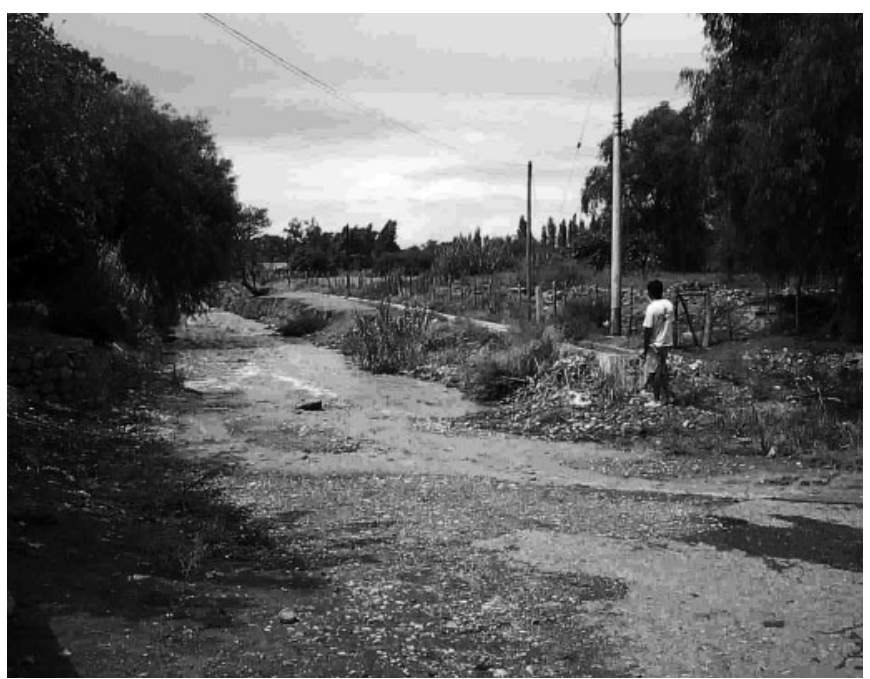

Figure 4 15th street, view to the east on March 8, 2003.

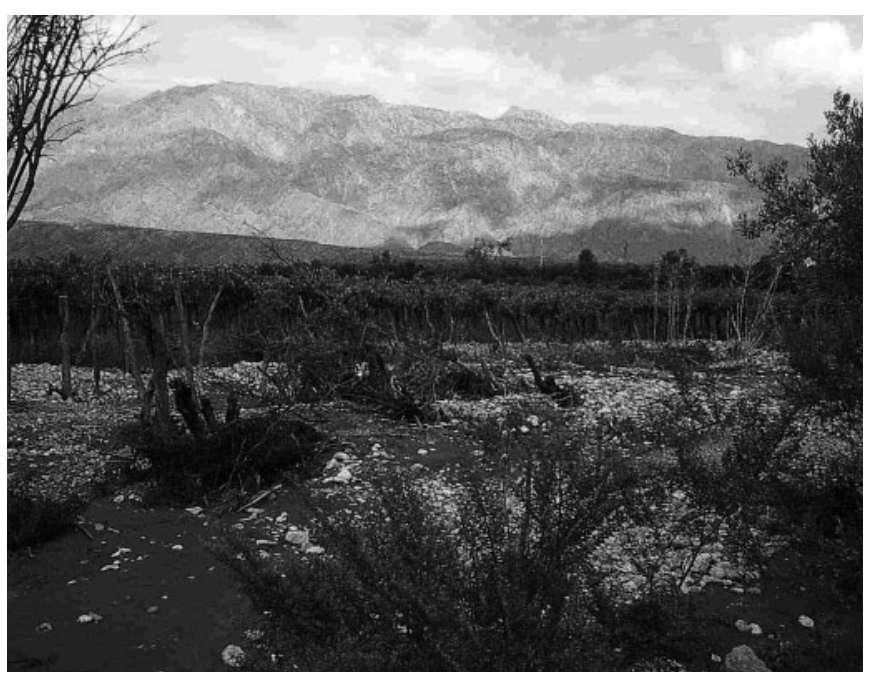

Figure 5 Grape field affected by flooding.

the entrance of the local hospital and numerous families had to be evacuated.

On March 8th, 2003, as a consequence of a violent rainfall of nearly $20 \mathrm{~mm}$ in just 2 hours, alluvium overflowed the dams and collectors built as defenses and reached Highway 40 . As a result of the damage, the highway had to be closed for repairs for several hours (Figure 2). The flood channeled through 13th Street and 15th Street (Figures 3 and 4), which became natural rivers and flooded grape fields (Figure 5).

The flood severely eroded one of the sides of a dam located in 16th Street, one of the main town streets, that had been filled during previous floods (Figure 6). As a result, water flowed over 16th Street, creating a deep trench alongside.

\section{Conditions favoring flooding and the deposition of alluvium}

These are:

1. The climatic conditions of the region: with heavy storms characterized by high rainfalls during short periods of time. These strong and concentrated rainfalls result in abundant superficial runoffs with poor infiltration.

2. The geomorphologic conditions constitute the other indispensable factor in the generation of floods. Floods frequently originate in 


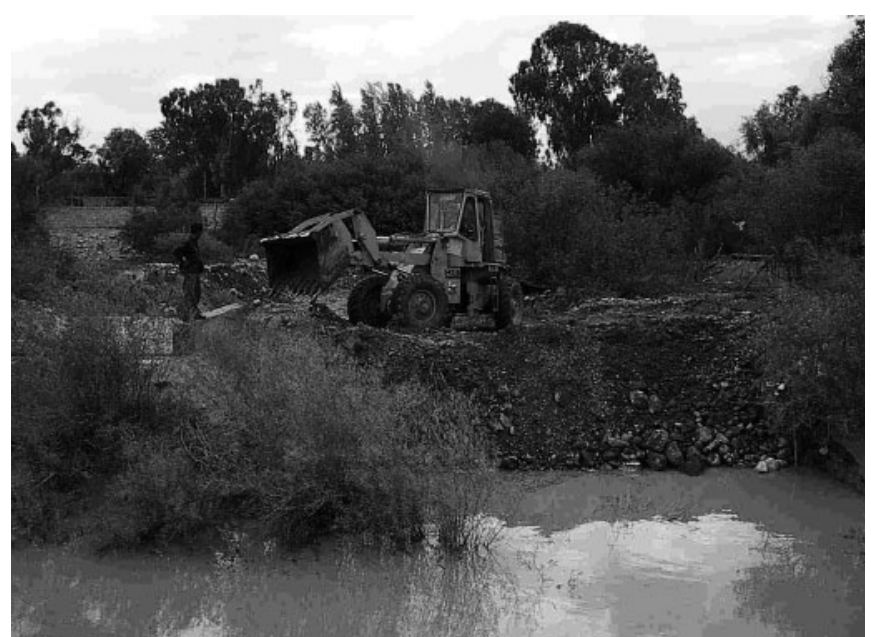

Figure 6 Reparation works in a defense dam after flooding.

the hills of the Chica de Zonda range, with slopes reaching up to $37 \%$. In the piedmont the slopes are of $11 \%$. In the lower parts where the hills gradually grade into valleys, the flattened slopes constitute the area of sediment accumulation. The cultivated areas are located in this sector, with a general slope of $0.8 \%$.

3 . The geological conditions determine the type of accumulations found in the hydrographic basins of the eastern flank of the Chica de Zonda range. The origin of this material can be traced to alluvial fans, alluvial cones, hillside wastes, riverbeds and terraces. It is also important to consider the tectonics of the region. The eastern piedmont has been affected by modern faulting scarping predominantly against the regional slope, that uplifting underlying Tertiary sedimentites (Figure 7).

4. The human activity modifying the natural landscape includes piedmont farming, garbage dumps, and civil works such as irrigation channels, bridges and high voltage lines. All of these affect the hydrological conditions, the drainage regime, the stability of soils and rocks, and their erosion resistance.

5. The hydrographic landscape consists mainly of elongated basins that favor a rapid water discharge in the form of strongly incised streams and rivers of alluvial fans.

6. The sparse natural vegetation, with predominant cacti, burro weeds and other species of reduced size, also contributes to flooding.

\section{Active and inactive channels}

Martos (1995) recognizes up to 5 different levels of Quaternary alluvial fans designated as cones-glacís, which are related to autochthonous streams originated from the range. Within these levels, active and inactive channels can be easily recognized (Figure 8). The extension of these cones within the Chica de Zonda range piedmont was established during a series of geomorphologic studies, in which topographic maps and aerial photography were used.

The active areas are frequently flooded with modern flash floods, having a poor development of the drainage pattern, and the desert varnish or desert pavement has not taken shape. These areas are found in lower topographies relative to older levels, which do possess desert varnish and desert pavement, in addition to a much better defined drainage pattern.

\section{Conclusions and recommendations}

From a geologic point of view, the floods do not constitute abnormal events. However, at a human scale they acquire a catastrophic char-

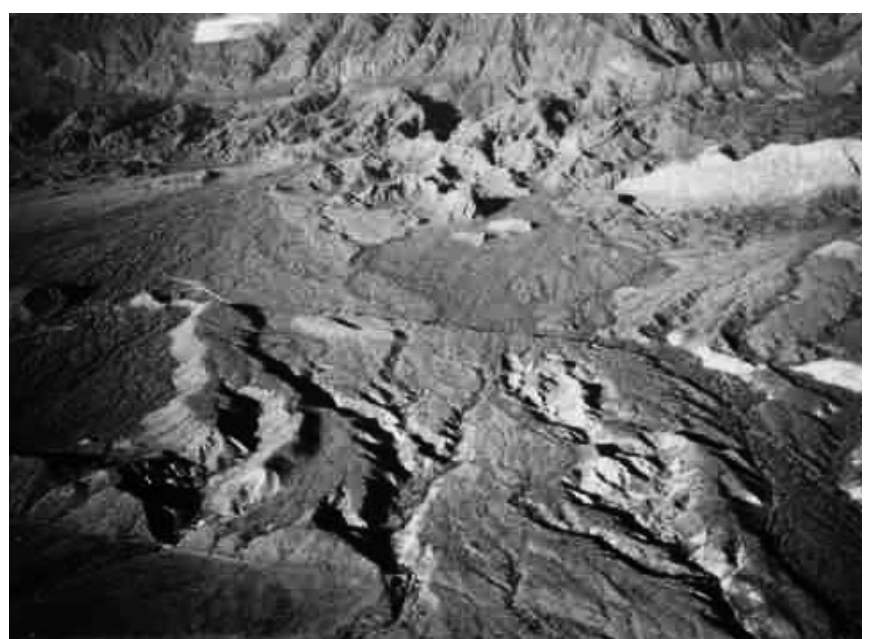

Figure 7 Chica de Zonda eastern piedmont.

acter, as communities respond to characteristic actions of natural geodynamics in the morphologic evolution processes.

Due to the mountainous nature of the department, the occupation and population's concentration and farming have been forced within a geodynamically active area, in lands subjected to high levels of danger because of seasonal alluviums.

Most exposed areas are adjacent to 13th and 15th Streets, especially vineyards, small cellars and farms. By assigning a value of USD 10,000.00/ hectare of vineyard, USD 5,000.00 for houses and at least USD 50,000.00 for each of the existent cellars in the area,

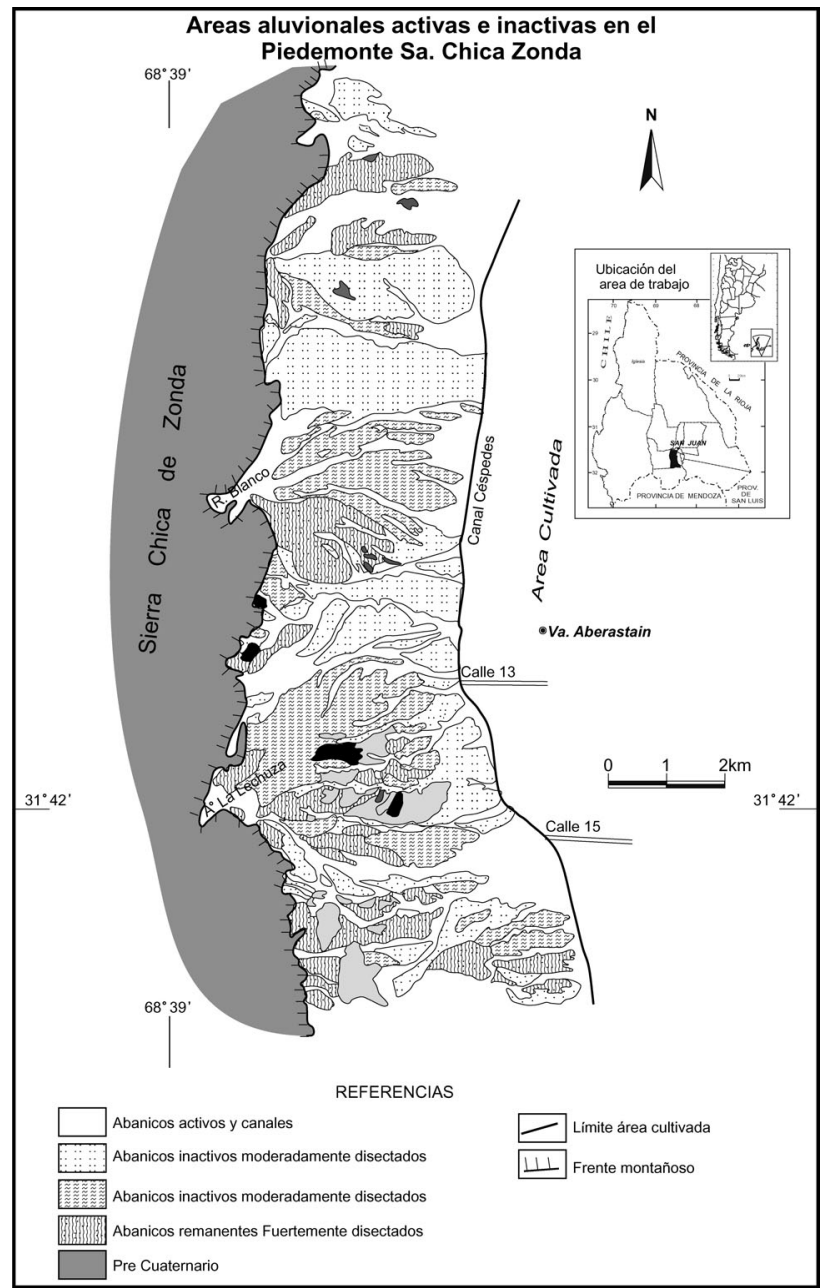

Figure 8 Active and inactive channels. 
the losses could reach the million of dollars in the case of a great flood. Costs and losses of repairing irrigation channels, high voltage lines and defense works would also be high.

The magnitude and consequences of the damage caused by recent floods reaffirm the importance of setting in place the appropriate mitigation measures to minimize future loss of property damage from events of similar or even greater magnitude. The selection and design of appropriate mitigation measures will have to be based on the rate of recurrence of events with different magnitude, and the economics, feasibility, and acceptability of preventing damage and casualties (United Nations, 1996).

Interdisciplinary cooperation among geologists, engineers, architects, planners and economists is essential to elaborate efficient political rules of local and regional urban development.

To minimize the effects of the alluvial fan flooding hazard in the department, it is necessary to start with the planning of intensive and extensive action tasks.

The intensive interventions should have as a main objective retaining and detaining the runoff, reducing erosive activity. These measures should include the construction and subsequent proper maintenance of the existing hydraulic works in the area, and construction of new ones as necessary. The most common method of entrapment of flowing debris is by concrete crib-type check dams with low-flow center sections or by debris basins. Structures of this nature have a high initial cost and generally require annual or more frequent maintained. Other useful constructions against lateral erosion are, concrete plates, walls, palisades and pile strings. Many of these civil works already exist in the department but are not maintenaned. They have deteriorated or filled with debris and garbage, losing effectiveness.

Streets constructed parallel to flow channels, minimize the destructive effects of the incoming floods.

Extensive interventions imply the creation of a set of conditions intended to improve the habitat towards the natural regulation of the floods. These include reforestation projects; the creation of forest protection strips to regulate the surficial drainage, preferable with indigenous species; changing the regime of the waters, and consolidating surficial soils. These extensive interventions should be designed as a complement of the civil works.

Finally, it should be necessary to establish a series of norms intended to protect and to regulate the use of the land. These rules should limit agricultural activity within certain stipulated limits and should regulate the construction of buildings according to minimum safety standards.

Monitoring, early warning, and evacuation procedures are part of other extensive approaches to mitigate floods hazards. In order to increase the ability of emergency managers to respond to future potential events, early warning systems based on weather forecasts and rainfall information should be developed.

\section{References}

Ayala Carcedo, F., 1993. "Estrategias para la reducción de desastres naturales. Investigación y Ciencia 200: 6- 13. Madrid.

Bastias H, 1986. "Fallamiento cuaternario en la región sismotectónica de Precordillera". Tesis Doctoral (Inédito). Facultad de Ciencias Exactas, Físicas y Naturales, Universidad Nacional de San Juan, 160 p. San Juan.
Clarke, A.O., 1996, Estimating probable maximum floods in the Upper Santa Ana basin, Southern California, from stream boulder size: Environmental \& Engineering Geoscience, v. 2, pp. 165-182.

Martos, L., 1995. Fallamiento cuaternario en el borde oriental de Precordillera entre el río San Juan y el río de Los Pozos. Universidad Nacional de San Juan. Tesis Doctoral (Unpublished).

Poblete, A. y Minetti, J., 1999. Configuración espacial del Clima de San Juan. Síntesis del Cuaternario de la Provincia de San Juan. XI Reunión de Campo del Cuaternario. CD-ROM. San Juan, Argentina.

National Academy Press, 1996. Alluvial Fan Flooding. http://www.nap.edu/books/all

United Nations, 1996, Mudflows, Experience and Lessons Learned from the Management of Major Disasters, Chapter 4, Mudflow prevention: United Nations Department of Humanitarian Affairs, Geneva, p.21-42.

Tello G. y Perucca, L., 1993. "El Sistema de Fallamiento de Precordillera oriental y su relación con los sismos históricos de 1944 y 1952, San Juan, Argentina." $12^{\circ}$ Congreso Geológico Argentino y $2^{\circ}$, Congreso de Exploración de Hidrocarburos, 3: 246-251. Mendoza.

Wieczorek, G.F., Larsen, M.C., Eaton, L.S., Morgan, B.A. and Blair, J. L. Debris-flow and flooding hazards associated with the December 1999 storm in coastal Venezuela and strategies for mitigation. U.S. Geological Survey. Open File Report 01-0144

Laura Perucca graduated in Geology from the University of San Juan, Argentina in 1995. She is an Adjunt Researcher of the National Research Council of Argentina (CONICET) and Professor of Photogeology in the San Juan National University. Her main interests and publications comprise all aspects of natural hazards. She has been working on neotectonics, seismic risk assessment and currently, fan flood hazard.

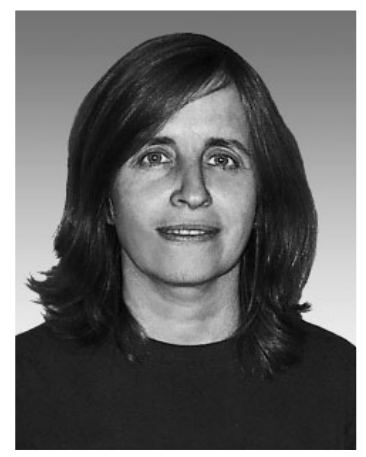

Juan Paredes graduated in Geology from the University of San Juan, Argentina in 1992. He is a professor of Geomorphology in the University of San Juan. His researches have been mainly concentrated on Neotectonics and geomorphology. He is currently a senior geologist in the mining industry.

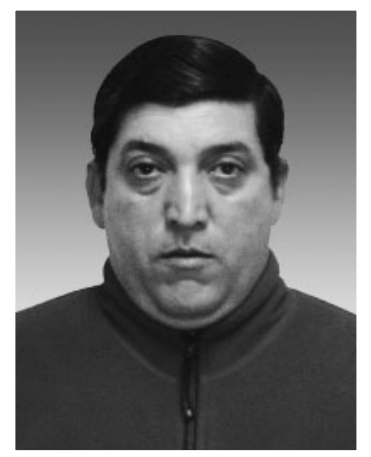

